\title{
"Economic Analysis of Pulses Production Their Benefits and Constraints"(A Case Study Of Sample Villages Of Assan Valley Of Uttarakhand, India)
}

\author{
Sunit Kumar ${ }^{1} \&$ V.A. Bourai ${ }^{2}$ \\ ${ }^{1}$ Research Scholar, Department of Economics SGRR (PG) College Dehradun (Uttarakhand), India \\ ${ }^{2}$ Principal \& Ex-Head Department of Economics SGRR (PG) College Dehradun (Uttarakhand) India
}

\begin{abstract}
Pulses on account of their vital role in nutritional security and soil ameliorative properties have been an integral part of sustainable agriculture since ages. However the production of pulses in Uttarakhand has drastically came down in the period, 1990-91 to 2007-08. The pulses data of Government of Uttarakhand, directorate of Agriculture, 2008, shows that the winter pulses (lentil and chickpea) area declined in this period 5 thousand hectare. The reasons for declining the pulses were most of the farmers are economically inefficient in producing pulses in the region.

The researcher has made an effort to find out the out the economics, benefit, and constraints of pulses in the state of Uttarakhand. This study has revealed that the rotation of chickpea and pigeon pea reduces the use of chemical fertilizers and also enhances the output of paddy and wheat significantly.

The entire Assn Valley which is the part of Doon valley of Uttarakhand was selected for the study. The sample was randomly taken of 275 cultivars producing or not producing pulses. Participatory Rural Appraisal (PRA) approach was chosen as research method and was completed by household interviews based on a semistructured questionnaire.
\end{abstract}

Key Words: Pulses production, benefits and constraints

\section{Introduction}

Traditionally pulses have been considered important elements of cropping systems in the IndoGangatic Plains. They were popular because of their importance as a source of protein and ability to fix atmospheric nitrogen $(\mathrm{N})$ and thus improve soil fertility [Joshi 1998] ${ }^{1}$.

With the introduction of irrigation and due to high profitability of alternative sources of soil nutrients in the form of inorganic fertilizers in the mid- 1960s, legumes were replaced or relegated to marginal lands. During the late 1960s and early 1970s, a large area under legumes in the Indo-Gangetic Plain (IGP) was substituted by high- yielding varieties of rice (Oryza sativa) and wheat (Tritium aestivum). The new technology of rice and wheat substantially changed the agricultural scenario and largely contributed to increase in agricultural production in the IGP.

With the passage of time, excessive use of chemical fertilizers and irrigation in rice and wheat to maintain their productivity has created an imbalance in soil fertility and threatened the sustainability of the most productive food grain belt in South Asia [Hobbs and Morris 1996] ${ }^{2}$. Legumes are an effective source of reversing the process and can contribute significantly to achieving the twin objectives of increasing productivity and improving the sustainability of the rice and wheat- based cropping system in the IGP [Ahlawat et al. 1998; Lauren et al. $1998^{4}$; Yadav et al. $1998^{5}$ ].

In sample villages of Assan Valley, the area under pulses has declined sharply since 1990 till date. The same trend is found in the state of Uttarakhand as well as in India. The secondary data has revealed that the trend is same in the SAARC Countries too. This is the major cause of continuous price rise of pulses in India. Pulses production in Uttarakhand drastically came down in the period, 1990-91 to 2007-08. The data given by the directorate of Agriculture, Uttarakhand 2008, shows that the winter pulses (lentil and chickpea) area has declined in this period that is 5 thousand hectare. The Production has declined up to 5.78 and 1.41 thousand metric tonnes of lentil and chickpea, respectively. The productivity has declined -2.19 qt/ha in chickpea and $2.15 \mathrm{qt} / \mathrm{ha}$ in lentil. The area, production and productivity of kharif (rainy) pulses like pigeon pea almost remains static during the period 1990-2007, while the demand is continuously rising due to increasing population pressure.

This has happened due to persistent problems of biotic factors (insect and diseases), abiotic factors (climate, uncertain rainfall, excessive temperature, etc.), institutional and infrastructural constraints, technology related constraints etc. The state is threatened because most of the farmers are growing pulses inefficiently from economic point of view and cannot compete with other regions or states where production is more scientific and 
mechanized. This has brought pulses economics in state of disequilibrium which will further cause problems for the future generations.

This study has identified major limiting factors to the cultivation of pulses under rainfed conditions. Pod borer infestation, wilt and botrytis gray mold (BGM) disease have compelled farmers to substitute the area in favor of less remunerative crops or leave it unsown. This is the main cause for non utilization of the rabi (winter) fallow lands.

Non availability of good HYV seeds of pulses, lack of knowledge about HYVS, Poor technical guidance and untimely availability of inputs (agro-chemical, fertilizers, etc) are socio economic institutional constraints. Poor seed storage facilities, poor marketing facilities, poor transportation for marketing etc are the socio economic infrastructural constraints in pulses production in Assan Valley.

Farmers lack information on soil moisture conservation technologies and sowing technologies that help germinate the seed in low moisture regime. Farmers are poor. They lack sufficient capital to purchase critical inputs such as seed, fertilizers, and pesticides. Access to institutional credit is limited. Non-availability of these inputs particularly seed also restricts growing of rabi crops. Public extension system is weak to effectively deliver the technology, inputs, and information to the farmers. Farmers also perceive that in case the crop is sown and establishes well it is often prone to various insect pests and diseases. Grazing of crops by stray animals of the thinly distributed crop is a major limitation to cultivation of pulses. Low volume of produce and lack of markets may deprive the small and marginal producers to get the market prices.

\subsection{Material and Methods}

\section{Research Methodology}

The methodological approach employed in this research is both innovative and multifaceted. The researcher adopted a form of Participatory Research Appraisal (PRA) and Rapid Rural Appraisal (RRA) with some applied features, which were made popular by well known development researcher Robert Chambers [Chamber $\left.1981^{6}, 1992\right]^{7}$. Although all the principals of PRA, important to this research should be adumbrated. Thus the primary task of PRA is the "enlightenment and awakening of common people" [Fals Borda and Rahman 1991]. . RRA, Rapid Rural Appraisal methods, PRA consists of a series of techniques for quick research \& information that generates results of less apparent precision, but greater evidential value, than classic quantitative survey techniques [Chambers, 1992] $]^{7}$. It emphasizes the importance and relevance of situational local knowledge, and the necessity to identify rightly key element than achieving spurious statistical accuracy. It is based on listening research and on a creative combination of interactive methods and verification, including "triangulation" of data from different sources using two different methods to view the same information. The main PRA techniques used were as follows: map of study area, transects walks, seasonal visits, problem listing and analysis, problem ranking and opportunity assessment. The second Part of the survey was dedicated to household interviews using a semi-structured questionnaire in order to complete the PRA data. Secondary data collected from various annual agriculture reports Government of Uttarakhand and India and computed from three moving average method.

\subsection{Area of study}

Assan Valley is situated in the western part of Doon Valley, located at the south of Uttarakhand and the west of Dehradun. The Valley covers an area of about $30 \mathrm{~km}$ in length and $20 \mathrm{~km}$ in width which is approximately $600 \mathrm{sq} \mathrm{km}$. in size. The study area falls in the $30^{\circ} 15^{\prime} \mathrm{N}$ and $77^{\circ} 45^{\prime} \mathrm{E}$ comprises the western part of the "Doon Valley" located in the district of Dehradun, Uttarakhand [Parsad and Verma 1975]'. The mean annual temperature ranges from $30.85^{\circ} \mathrm{C}$ during summer and $15.22^{\circ} \mathrm{C}$ during winter. The mean annual rainfall is $1700 \mathrm{~mm}$. [Martin and Saha 2007] ${ }^{10}$

\subsection{Sampling}

The random stratified sampling was employed for the research. Two hundred and seventy five farmers were selected randomly from nine villages across northern and southern part of Assan Valley. The number of villages chosen from two regions of the valley was based on the extent of pulses production in that region. The table no. 1 shows that 174 farmers were selected from northern part of the Assan Valley and 101 sample farmers from southern side of Assan valley. The percentage of sample household in northern part of the Valley was 63.27 while 36.73 percent in southern part of Assan Valley. Villages were selected randomly from these region and pulse producers selected randomly from each village. The number of pulses producers selected in each region was based on the proportion of land sown in each region (table 1). 
"Economic Analysis Of Pulses Production Their Benefits And Constraints"(A Case Study Of Sample)

Table 1. Number of villages and sample households in different regions of Assan valley.

\begin{tabular}{|c|c|c|c|c|}
\hline \multicolumn{2}{|l|}{ Region } & Village & Sample farmers & $\%$ of total sample \\
\hline Northern part of & Assan & Nayagaon & 35 & 12.72 \\
\hline valley & & Signiwala & 48 & 17.45 \\
\hline & & Sabhawala & 46 & 16.72 \\
\hline & & Ramgarh & 25 & 9.10 \\
\hline & & Jingwreri & 20 & 7.27 \\
\hline Southern part of & Assan & Jhajhra & 26 & 9.45 \\
\hline valley & & Bahuwala & 27 & 9.81 \\
\hline & & Sahaspur & 27 & 9.81 \\
\hline & & Channchak & 21 & 7.63 \\
\hline Total sample & & 9 & 275 & 100.00 \\
\hline
\end{tabular}

\section{Result and Discussion}

\subsection{Legumes in Uttarakhand}

In Uttarakhand, the area under Rabi (winter) pulses decreased sharply during 1990-2007. The area under chickpea has marginally declined while in lentil it declined rapidly during the period 1990-2007 (fig. 1). Area decreased up to 4 thousand hectare in lentil, while in chickpea, it decreased more than 1 thousand hectare during the period of 1990-2007. In kharif (rainy) pulses, the area under pigeon pea remain almost static, while in black gram it fluctuates almost between 9.5 thousand hectare to12.5 thousand during the period of 1990-2007. The production of all pulses has declined except black gram (figure 2). Again the production of winter pulses declined rapidly. The production of lentil was 13.19 thousand metric tonnes in 1990 which decreased up to 7.41 thousand metric tonnes in 2007. The production of chickpea also declined from 2.07 thousand metric tonnes in 1990 to 0.66 thousand metric tonnes in 2007. The production of pigeon pea almost remains static during this period (figure 2). Again the yield of all pulses has also declined except black gram during the period of 19902007 (figure 3). Only in black gram, the positive trend in production and yield is due to increase in area during this period. The pulses production is declining in the region [Directorate of agriculture, Government of Uttarakhand 2008 $]^{11}$.

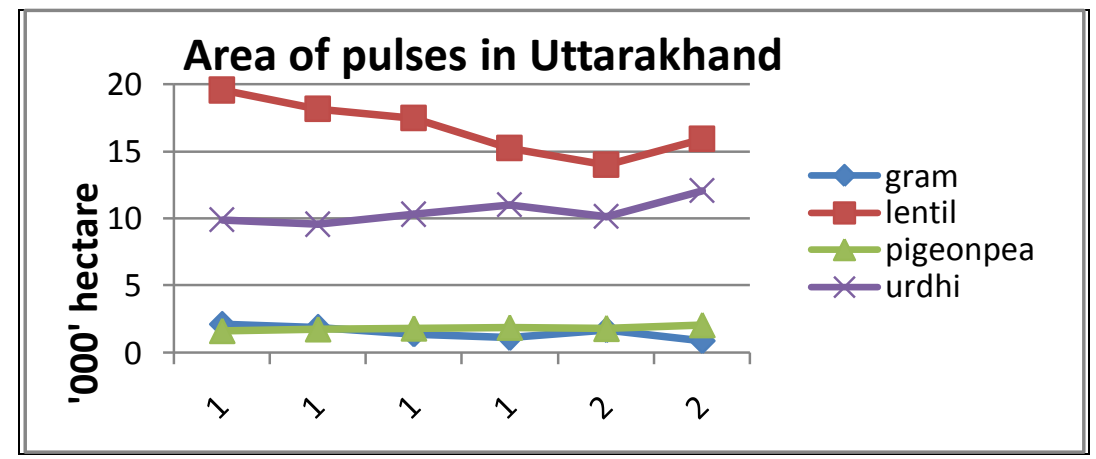

Fig. 1 Trend in area of major pulses in Uttarakhand during 1990-2007 (area in '000' ha)

Source: Directorate of Agriculture, Government of Uttarakhand, 2009-10

Note: Data calculated from three year moving average method

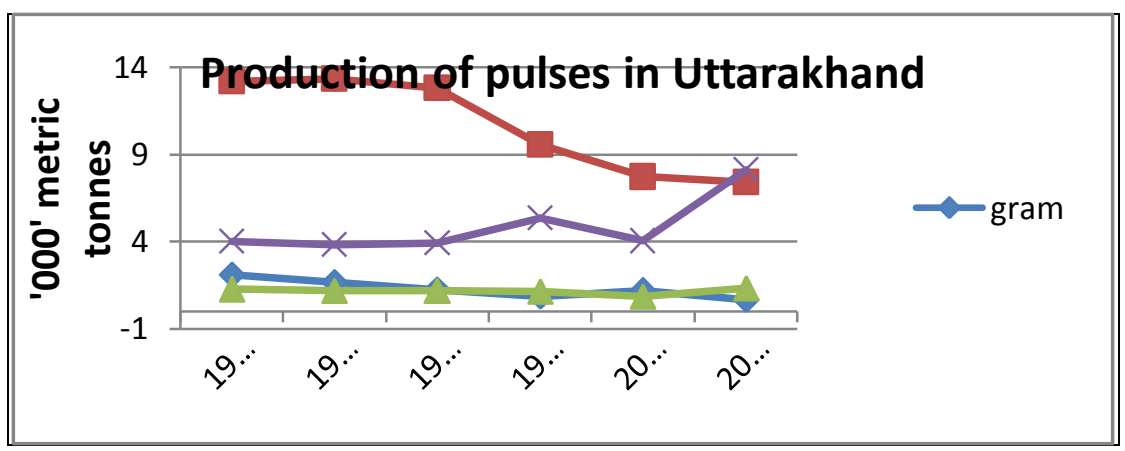

Fig. 2 Trend in production of major pulses in Uttarakhand during 1990-2007 (production in ' 000 ' metric tonnes)

Source: Directorate of Agriculture, Government of Uttarakhand, 2009-10

Note: Data calculated from three year moving average method 


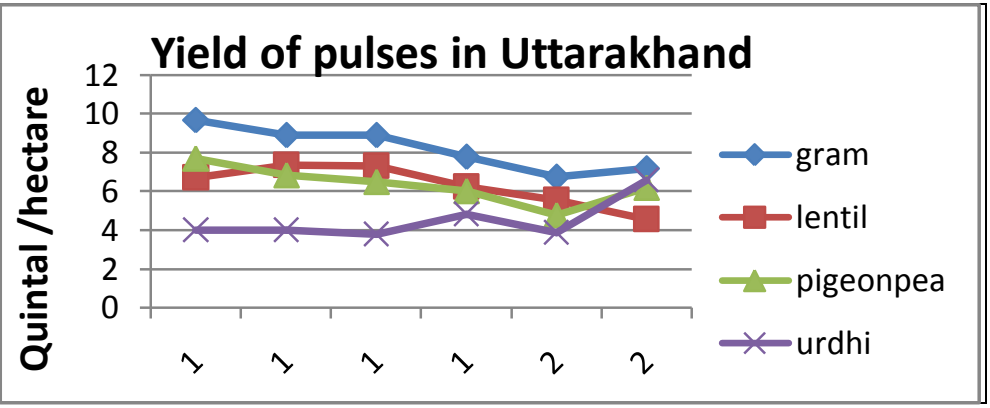

Fig. 3 Trend in yield of major pulses in Uttarakh and during 1990-2007(yield quintal/ha) Source: Directorate of Agriculture, Government of Uttarakhand, 2009-10

Note: Data calculated from three year moving average method.

\subsection{Legumes in Assan Valley}

\subsubsection{Winter season crops}

In the sample farms of Assan Valley, more than $90 \%$ of the average total cultivated area during the winter was wheat and sugarcane and remaining $10 \%$ of the total cultivated area was under lentil, mustard, chickpea, and grass (barley) etc (table 2). There was some variation in enterprise choice across the different regions. Lentil, chickpea and mustard appeared to be minor crop covering only $4.26 \%, 1.18$ and $0.45 \%$ of the total average cropped area during winter (table 2). In some of the study villages not even a single farmer is cultivating chickpea due to pod borer (insect), wilt (disease) and other a biotic, biotic and technology related constraints. In winters the pulses are again not the choice of the farmers. The table 2 shows that only few farmers' choice is winter pulses.

Table 2. Cropping pattern during winter season on sample farm in different part of Assan Valley (\% of winter cropped area)

\begin{tabular}{|l|l|l|l|}
\hline Crop & Northern part & Southern part & Average \\
\hline Wheat & 77.30 & 61.91 & 69.60 \\
\hline Sugarcane & 14.65 & 26.96 & 20.80 \\
\hline Lentil & 3.68 & 4.84 & 4.26 \\
\hline Mustard & 0.36 & 0.55 & 0.45 \\
\hline Chickpea & 0.26 & 2.10 & 1.18 \\
\hline Grass & 2.24 & 3.90 & 3.07 \\
\hline Other & 1.51 & 0.00 & 0.75 \\
\hline
\end{tabular}

Source: Based on household survey in study area, 2009-10.

Note: Sugarcane crop is long duration crop that occupy area even winter.

\subsubsection{Rainy season crops}

Rice and maize are staple crops during rainy season in Assan Valley followed by sugarcane. In sample farm, more than $78 \%$ average total cultivated area during the rainy season was under rice, maize and sugarcane and remaining $22 \%$ total cultivated area was with black gram, pigeon pea, mustard, pachrangi (a many color pulse), ground nut, grass (bazra and green gross) etc. As far as pulses are concerned, black gram and pigeon pea are important minor crops during rainy season, covering an average cultivated area $4.19 \%$ and $1.70 \%$ of the gross cropped area (table 3). Pachrangi (a many color pulse) and cowpea also appeared to be minor crop in Assan valley covering only $1.40 \%$ and $0.28 \%$ of the total average cropped area.

Table 3. Cropping pattern during rainy season on sample farms in different region of Assan Valley (\% of rainy cropped area)

\begin{tabular}{|l|l|l|l|}
\hline Crop & Northern part & Southern part & Average \\
\hline Paddy & 33.35 & 17.42 & 25.39 \\
\hline Maize & 29.13 & 35.40 & 32.27 \\
\hline Sugarcane & 14.65 & 26.96 & 20.80 \\
\hline Black gram & 3.60 & 4.79 & 4.19 \\
\hline Mustard & 1.66 & 2.76 & 2.21 \\
\hline Pigeon pea & 0.72 & 2.66 & 1.70 \\
\hline Pachrangi & 1.54 & 1.25 & 1.40 \\
\hline Cowpea & 0.49 & 0.07 & 0.28 \\
\hline
\end{tabular}




\begin{tabular}{|l|l|l|l|}
\hline Groundnut & 1.92 & 0.00 & 0.96 \\
\hline Grass & 7.93 & 6.27 & 7.10 \\
\hline Peas & 0.00 & 1.88 & 0.94 \\
\hline Other & 5.04 & 0.38 & 2.71 \\
\hline \multicolumn{2}{l}{ Note: Sugarcane crop is a long duration crop. }
\end{tabular}

\subsection{Factor share of pulses production}

Pulses like chickpea, lentil, black gram and pigeonpea are less labor-intensive crops; and cheap comparatively to other competitive winter crops like wheat, etc [Pande et al, 2003] ${ }^{12}$. On an average, human and bullock (or machine) labor constituted $84 \%, 80 \%, 81 \%$ and $78 \%$ share of the total operational expenses for chickpea, lentil, black gram and pigeonpea production, respectively (table 4). Average share of seed in the total operational expenses were $11 \%$ in chickpea, $7.35 \%$ in lentil, $19 \%$ in black gram and $11.65 \%$ in pigeonpea production. The rest of the factor share was spent on compost fertilizers and technology inputs and to control insects and diseases. Pulses require less consumption fertilizers comparing to cereal crops like wheat etc. Only $4 \%$ in cost of the total cost of production of chickpea production were spent on fertilizers and compost fertilizers, while $12.50 \%$ in lentil, 9.55 in black gram and $9.36 \%$ in pigeonpea cost of the total operational cost were spent on fertilizer and compost fertilizer. The cost on the control of pest and diseases is almost negligible on pulses in Assan valley of Uttarakhand. Despite of suffering huge crop damages; due to insects and disease, farmers rarely applied insecticides or pesticides for pulses cultivation. Only $1 \%$ in chickpea, $0.40 \%$ in lentil and $0.06 \%$ in pigeonpea share are spent on pesticides out of the total expenses (table 4). There is no factor share cost spent on irrigation because legumes are cultivated in rainfed conditions. The farmers of Assan valley of Uttarakhand are not aware about the HYV seeds and the latest techniques and other essential land preparation techniques. Pulses can be grown with minimum irrigation in entire Assan valley. Thus, it also reduces the cost of legumes production.

Table 4 Average factor (input) share for pulses production per hectare in Assan Valley (\% of total cost)

\begin{tabular}{|l|l|l|l|l|}
\hline Inputs & Chickpea & Lentil & Black gram & Pigeonpea \\
\hline Seed & 11.00 & 7.35 & 9.12 & 11.63 \\
\hline Fertilizers & 4.00 & 12.50 & 9.55 & 9.36 \\
\hline Pesticide & 1.00 & 0.40 & 0.00 & 0.06 \\
\hline Irrigation & 0.00 & 0.00 & 0.00 & 0.00 \\
\hline Labor & 55.00 & 49.50 & 53.33 & 50.73 \\
\hline Bullock/Machine & 29.00 & 30.25 & 28.00 & 28.22 \\
\hline
\end{tabular}

Source: Based on household survey in study area, 2009-10.

\subsection{Average Cost of pulses production}

The average cost of pulses production per hectare is shown with the help of the following table number 5. The average cost of pulses production, shows that there is cost variation in per hectare of average cost of production of different pulses. Black gram is the cheapest pulse as far as the cost of pulses production per hectare is concerned; it's a rainy season crop which is cost of pulses is Rs. 9740 per hectare. While in winter pulses, the cost of production per hectare for chickpea is lowest which is Rs 11982 per hectare (table 5). The price mechanism of chickpea and Black gram is favoring these two crops in the region of Assan valley

Table 5 Average inputs cost (per hectare) of pulses production

\begin{tabular}{|l|l|}
\hline Crop & Amount (Rs) \\
\hline Chickpea & 11982 \\
\hline Lentil & 13804 \\
\hline Black gram & 9740 \\
\hline Pigeon pea & 12148 \\
\hline
\end{tabular}

Source: Based on household survey in study area, 2009-10.

\subsection{Average yield of pulses production}

The yield of pulses production $(\mathrm{kg} / \mathrm{ha})$ also varies from pulses to pulses and region to region. The average yield of pigeon pea production was highest $(602.88 \mathrm{~kg} / \mathrm{ha})$ comparing to other pulses production in Assan valley and the average yield of black gram production was lowest $(162.40 \mathrm{~kg} / \mathrm{ha})$. The average yield of lentil and chickpea production in the valley was $494.41 \mathrm{~kg} / \mathrm{ha}$ and $229.10 \mathrm{~kg} / \mathrm{ha}$ respectively (table 6). Average yield of byproduct of pulses was $400 \mathrm{~kg} / \mathrm{ha}$ in chickpea, $900 \mathrm{~kg} / \mathrm{ha}$ in lentil, $300 \mathrm{~kg} / \mathrm{ha}$ in black gram $800 \mathrm{~kg} / \mathrm{ha}$ 
in pigeon pea (table 6). The farmer uses these fodders for farm animal which is also significant from the economic point of view. It helps in dairy farming. The total output of pulses production (grain yield and fodder yield) was highest in lentil (Rs 17591) while lowest in black gram (Rs 6706).

Table 6 Average outputs (per hectare) from cultivation of pulses production

\begin{tabular}{|c|c|c|c|c|c|}
\hline \multirow[t]{2}{*}{ Crop } & \multicolumn{2}{|c|}{ Grain yield } & \multicolumn{2}{|c|}{ Fodder yield (by product) } & \multirow{2}{*}{$\begin{array}{l}\text { Total output } \\
\text { (Rs) }\end{array}$} \\
\hline & (kg) & (Rs) & $(\mathrm{kg})$ & (Rs) & \\
\hline Chickpea & 229.10 & 8121 & 400 & 800 & 8921 \\
\hline Lentil & 494.41 & 15791 & 900 & 1800 & 17591 \\
\hline Black gram & 162.40 & 6256 & 300 & 450 & 6706 \\
\hline Pigeon pea & 602.88 & 14267 & 800 & 1600 & 15867 \\
\hline
\end{tabular}

Source: Based on household survey in study area, 2009-10.

\subsection{Net returns from Legumes cultivation in Assan Valley}

The production of legumes on sample farms in different parts of the Assan Valley has been found from the economics point of view in a different way. Lentil and pigeon pea are profitable legume, while chickpea and black gram are showing negative monetary returns. The net profit was only Rs 3787/ha in lentil and Rs 3719/ ha in pigeon pea, while black gram and chickpeas net profit is Rs. - 3061/ha and Rs - 3034/ha, which is negative in monetary terms (table 7). The estimated benefit cost ration (BCR) of legumes were 0.74 in chickpea, 1.27 in lentil, 0.68 in black gram and 1.30 in pigeon pea. We have estimated the cost benefit ratio from growing chickpea, lentil, black gram and pigeonpea on per hectare basis using recent prices. This will assist understanding of the likely benefits and investment requirements by individual farmers and also give indications on the total benefit from introduction of legumes in rice fallows or fallow land to the national economy of India in terms of employment creation and increase in output. Despite of losses in pulses production, it is significant from the economic point of view, its output is saving fertilizers and increases in yield of subsequent crops is not included in its economics.

Table 7 Net returns (per hectare) from cultivation of pulses

\begin{tabular}{|l|l|l|c|}
\hline \multirow{2}{*}{ Crop } & Returns & \multicolumn{3}{|c|}{} \\
\cline { 2 - 4 } & $\begin{array}{l}\text { Gross returns } \\
(\mathrm{Rs})\end{array}$ & $\begin{array}{l}\text { Net returns } \\
(\mathrm{Rs})\end{array}$ & $\begin{array}{c}\text { Benefit cost ratio (BCR) } \\
(\mathrm{Rs})\end{array}$ \\
\hline Chickpea & 8921 & -3061 & 0.74 \\
\hline Lentil & 17591 & +3787 & 1.27 \\
\hline Black gram & 6706 & -3034 & 0.68 \\
\hline Pigeon pea & 15867 & +3719 & 1.30 \\
\hline
\end{tabular}

Source: Based on household survey in study area, 2009-10.

\subsection{Economic efficiency of farmers in pulses production}

Pigeon pea is the only pulse crop in Assan Valley in which maximum farmers (57\%) is economically efficient and the remaining $43 \%$ pigeon pea cultivators are economically inefficient from economic point of view. In case of chickpea, $77 \%$ of average chickpea cultivars are economically inefficient in the production of chickpea and remaining 23\% chickpea farmer are perfectly efficient (table 8). The economics of lentil cultivation shows that, $43.70 \%$ average sample farmer is perfectly efficient and remaining fall under different economic inefficient categories. As far as the production of black gram is concerned, only $21 \%$ farmers in Assan Valley are perfectly efficient and the remaining 79\% are inefficient from economic point of view. The main reason of inefficiency of farmers is occurrence of pod borer (insect), wilt (disease), climate and other constraints. At present, the chickpea farmers are negligible in size due to above said constraints.

Table 8 Distribution of sample farmer according to economic efficiency of pulses production (\% of total sample).

\begin{tabular}{|l|l|l|l|l|}
\hline Cost-price Ratio & Chickpea & Lentil & Black gram & Pigeonpea \\
\hline$>1.00$ & 23.00 & 43.70 & 21.00 & 56.96 \\
\hline $0.75-1.00$ & 15.00 & 20.81 & 12.00 & 22.94 \\
\hline $0.50-0.75$ & 12.00 & 21.24 & 17.00 & 4.69 \\
\hline $0.25-0.50$ & 0.00 & 9.14 & 16.00 & 15.41 \\
\hline$<0.25$ & 50.00 & 5.01 & 34.00 & 0.00 \\
\hline
\end{tabular}

Source: Based on household survey in study area, 2009-10. 
(Note: $>1.00=$ perfectly efficient, $0.75-1.00=$ moderate low degree of inefficiency, $0.50-0.75=$ moderate high degree of inefficiency, $0.25-0.50$

$=$ high degree of inefficiency and $<0.25=$ perfectly inefficient).

\section{Benefits Of Legumes}

At present, the pulses are grown to meet household consumption, but there are non monetary or nutritional benefits that also arise from chickpea and pigeonpea cultivation. Chickpea a legume from the subfamily papillionoideae fixes nitrogen in soil, improves soil nitrate content and saves fertilizer costs and increases yield in subsequent crops [Pande, et al, $2003^{12}$, Joshi, P.K. $1998^{1}$ ]. Pigeon pea also does nitrogen fixation in soil [Kumar Rao et al., $1983^{13}, 1989^{14}$ and $1990^{15}$ ], improves soil nitrate content and saves fertilizers costs and increases yield of subsequent crops. There are two main benefits of pulses namely (a) reduced use of fertilizers in subsequent crops and (b) increase in yield of subsequent crops.

\subsection{Reduction in fertilizer}

Farmers reported drastic reduction in consumption of inorganic and organic fertilizers in plots where rice and wheat was grown in sequence with chickpea and pigeon pea as compared with wheat and rice. Farmers in rice, rotation of chickpea cultivation, use fertilizers $63.96 \mathrm{~kg} / \mathrm{ha}$ of urea, $53.12 \mathrm{~kg} / \mathrm{ha}$ Die and $12.21 \mathrm{trolley} / \mathrm{ha}$ of compost. The corresponding quantity of average fertilizers in rice when rotated with wheat was $83.31 \mathrm{~kg} / \mathrm{ha}$ of urea, $73.93 \mathrm{~kg} / \mathrm{ha}$ Die and 16.12 trolley/ha of compost in sample villages of Assan valley (table 9). Some farmers (southern part) also reported that they use less quantity of fertilizers in sequence with chickpea in comparison to wheat or fallow land. This shows that substantial saving in fertilizer that can be achieved. Study of [Joshi, P.K. 1998] ${ }^{1}$ supports our investigation, which emphasizes that the net savings in cost of fertilizers (about 47\%) applied to the rice crop if chickpea was included in the rotations, as against keeping the land fallows. The profitability of the subsequent rice crop was about $13 \%$ higher when it was rotated with chickpea. In rotation with pigeonpea farmers in wheat average fertilizer used $56.25 \mathrm{~kg} / \mathrm{ha}$ of urea, $91.66 \mathrm{~kg} / \mathrm{ha}$ Die and 9.37 trolley /ha compost (cow dung). While the fertilizers used in wheat was $72.91 \mathrm{~kg} / \mathrm{ha}$ of urea, $112.5 \mathrm{~kg} / \mathrm{ha}$ of Die when rotated with rice/maize in Assan Valley (table 9). This shows that substantial saving in fertilizer that can be achieved. There is no change of compost fertilizers quantity in rotated with rice.

Table 9 Fertilizer use per hectare sequence with pulses and sequence with competing crops in the season

\begin{tabular}{|l|l|l|l|l|l|l|}
\hline \multirow{3}{*}{ Fertilizer } & \multicolumn{3}{|l|}{ Sequence with chickpea } & \multicolumn{3}{l|}{ Sequence with wheat } \\
\cline { 2 - 7 } & Urea $(\mathrm{kg})$ & $\begin{array}{l}\text { Compost } \\
\text { (trolley) }\end{array}$ & $\begin{array}{l}\text { Die } \\
(\mathrm{kg})\end{array}$ & Urea $(\mathrm{kg})$ & $\begin{array}{l}\text { Compost } \\
(\text { trolley })\end{array}$ & $\begin{array}{l}\text { Die } \\
(\mathrm{kg})\end{array}$ \\
\cline { 2 - 8 } & 63.96 & 12.21 & 53.12 & 83.31 & 16.12 & 73.93 \\
\hline \multirow{3}{*}{ Fertilizer } & \multicolumn{2}{|c|}{ Sequence with pigeonpea } & \multicolumn{2}{|c|}{ Sequence with rice } \\
\cline { 2 - 7 } & Urea $(\mathrm{kg})$ & $\begin{array}{l}\text { Compost } \\
\text { (trolley) }\end{array}$ & $\begin{array}{l}\text { Die } \\
(\mathrm{kg})\end{array}$ & Urea $(\mathrm{kg})$ & $\begin{array}{l}\text { Compost } \\
\text { (trolley) }\end{array}$ & $\begin{array}{l}\text { Die } \\
(\mathrm{kg})\end{array}$ \\
\cline { 2 - 7 } & 56.25 & 9.37 & 91.66 & 72.91 & 9.37 & 112.5 \\
\hline
\end{tabular}

Source: Based on household survey in study area 2009-10.

\subsection{Savings of fertilizers of subsequent crop in monetary terms}

Savings of fertilizers in monetary terms of subsequent crops in sequencing with chickpea and pigeon pea is shown with the help of following table number 10. The table shows average saving of fertilizers was Rs 3544/ha in sequence with chick pea and Rs. 3415/ha in sequence with pigeon pea (table 10).

Table 10 Savings of fertilizers per hectare (in rupees) of subsequent crops in sequence with chickpea and pigeon pea

\begin{tabular}{|l|c|}
\hline Pulses & Amount (Rs) \\
\hline Sequence with chickpea & 3544 \\
\hline Sequence with pigeon pea & 3415 \\
\hline
\end{tabular}

Source: Based on household survey in study area 2009-10.

\subsection{Increase in yield}

The average yield of rice increased $21.78 \%(502.22 \mathrm{~kg} / \mathrm{ha})$, i.e., an additional income Rs. 10,040/household (table 11). These evidences clearly reveals that chickpea enriches soil fertility and improves savings in rice cultivation. There is evidence that in comparison to wheat or fallow land, chickpea has enhanced the yield of subsequent rice crops by 25-30\% [Pande et al, $2003^{12}$, Joshi, P.K, 1998 ${ }^{1}$ ]. Study of [Bourai et al. $2004]^{16}$ in Nepal, supports our investigations, which reveals that the Crop rotation with chickpea increases yield of paddy to 7.71 quintal/ha, i.e., an additional income of NRs 5397/household. The yield of wheat was higher 
when rotated with pigeon pea in comparison with rice/maize. The average yield of wheat increased by $33 \%$ (513.88 kg/ha), i.e., an additional income Rs.5690 per household (table 11).

There is no change in consumption of fertilizer as well as yield in subsequent crops when crop is rotated with lentil and black gram in the study area; while it is reported otherwise by the Agriculture Scientist.

Table 11 Rice and wheat yield under different rotations $(\mathrm{kg} / \mathrm{ha})$

\begin{tabular}{|l|l|l|l|l|l|}
\hline Crop & \multicolumn{2}{|c|}{ Crop rotation } & \multicolumn{2}{l|}{$\begin{array}{l}\text { Change in yield } \\
\text { rice \& wheat }\end{array}$} & $\begin{array}{l}\text { Value } \\
\text { addition }\end{array}$ \\
\hline \multirow{2}{*}{ Rice } & Chickpea-Rice & Wheat /Rice & $\mathrm{Kg} / \mathrm{ha}$ & Percent & (Rs/ha) \\
\cline { 2 - 6 } & 2845.77 & 2343.75 & 502.22 & 21.78 & 10,040 \\
\hline \multirow{2}{*}{ Wheat } & Pigeon pea-wheat & Rice/ wheat & $\mathrm{Kg} / \mathrm{ha}$ & Percent & $(\mathrm{Rs} / \mathrm{ha})$ \\
\cline { 2 - 6 } & 2652.77 & 2083 & 569.44 & 28.33 & 5,690 \\
\hline
\end{tabular}

Source: Based on household survey in study area, 2009-10

\subsection{Biotic constraints in chickpea production}

\section{Constraints In Pulses Production}

Compared to cereals, oilseeds and other pulses, chickpea faces more biotic constraints in production [Pande et al, 2003] ${ }^{12}$. Gram Pod borer (Helicoverpa armigera) was the key insect-pest and devastates chickpea production in all part of Assan Valley (table 13). According to farmers in PRA reports, Gram pod borer, local name Sundi kira (pest) infestation occurs every year. It was threat to food and nutritional security of farmers and could damage the entire chickpea crop.

Data presented in table 13 indicate that maximum yield loss (43.80\%) in chick pea was caused due to the attack of this notorious pest. Again maximum area (93.38 \%) under cultivation of chick pea was infested by gram pod borer. Attack of Cutworm, tobacco caterpillar and termites resulted in 30.09, 24.93 and 15.28 per cent loss in chick pea yield, respectively. Minimum area $(26.12 \%)$ was found under the influence of termites (table 13).This is an important pulse crop which is attacked by so many important diseases. Our survey indicates that maximum yield loss to chick pea was caused by fusarium wilt $(48.29 \%)$ and minimum by botrytis grey mould $(20.88 \%)$. Another diseases inflicting significant yield loss in chick pea were rhizoctonia root rot and ascochyta blight which caused 33.66 and 25.52 per cent yield loss, respectively. Maximum area $(72.16 \%)$ was found under the influence of wilt and minimum (29.20) influence under BGM (table 14). Wilt usually affects the crop early in the season owing to the susceptibility of seedling to the disease. Moreover, the disease is seed borne. BGM is a problem that usually strikes in the month of January when cool nights take more time to warm up. The mist hangs over the crop well into the morning and this is the ideal time for the growth of BGM on flowers and foliage [Pande et al. 2003] ${ }^{12}$. Study of [Reddy et al. $1990^{17}$ and Grewal 1988 $]^{18}$ supports our investigation, which emphasize that the Ascochyta blight (Ascochyta rabiae), BGM (Botrytis cinerea), Fusarium wilt (Fusarium oxysporum f.sp. ciceri) and Dry root rot (Rhizoctonia bataticola) are key diseases of chickpea, inflicting $20-40 \%, 25-35 \%, 10-15 \%, 5-20 \%$ yield loss, respectively.

\subsection{Biotic constraints in lentil production}

Lentil crop was attacked by only a few insect pests out of which lentil pod borer and termites were most important. Lentil pod borer was found to cause 24.3 percent loss in yield of lentil with 65.42 per cent area affected. Attack of Termites resulted in 31.4 percent yield loss and 62.50 per cent area affected due to this pest (table 13). Fusarium wilt and lentil rust were the two main diseases which are responsible for reduction in yield as well as area under cultivation of lentil. The yield loss due to fusarium wilt and lentil rust were recorded 29.98 and 21.22 per cent respectively, while they were found to infect the crop in 64.56 and 63.65 per cent area respectively (table 14).

\subsection{Biotic constraint in black gram production}

Among different insect pests of black gram, bihar hairy caterpillar and gram pod borer were two important insects, inflicting 19.95 and 34.24 percent yield loss to black gram crop in Assan valley. Termites were identified to cause 14.49 percent yield loss. Maximum area was found to be affected by gram pod borer $(81.46 \%)$, while incidence of bihar hairy caterpillar was at par with the gram pod borer. Distribution of termites was not uniform all over the Assan valley area and only 43.03 percent black gram fields were found to be infested with termites (table 13). During our survey on different diseases of black gram in Assan valley only two diseases viz. yellow mosaic and fusarium wilt were recorded to cause significant crop damage. The yield loss caused by yellow mosaic and fusarium wilt were 62.57 and 30.48 percent respectively. Maximum crop area was noticed to be infected by yellow mosaic disease ( $91.57 \%$ ), while fusarium wilt was recorded from 63.54 per cent black gram fields only (table 14). The yellow mosaic is a virus disease which is most destructive to the black gram and green gram in India. It was first reported in 1960 and now known to occur throughout the 

country. The loss in yield depends upon the stage at which the crop is infected by the disease. If the infection is in early stage then there may be total loss of grain yield [Singh, 2005] $]^{19}$.

\subsection{Biotic constraints in pigeonpea production}

In our household survey conducted during 2008-09 in Assan valley of Uttarakhand (table 13 \& 14) gram pod borer, Helicoverpa armigera was found to cause maximum yield loss in all the villages where pigeon pea was grown. The yield loss caused by this pest was estimated to the tune of 43.86 per cent (figure1), while 90.25 percent of the total cultivated area was infested by this insect (table 13). This pest feeds on foliage, when young and on the seeds in later stage after boring in to the pods. A single larva may destroy 30-40 pods before it reaches maturity, thus reducing the yield of crop. Probability of occurrence of this pest has been every year in the pigeon pea crop. Other insect pests which inflicted significant yield losses in pigeon pea were spotted pod borer, tur pod bug and termites. Termites were not a common feature of each and every field of village in the study area. Their distribution and subsequent yield loss to the crop depend upon the physical condition of the soil and amount of undecomposed organic matter present in it. Study of [Banu et al. 2005] $]^{20}$ supports our investigation, which emphasize that the gram pod borer, H. armigera is a key pest of pigeon pea, inflicting 80$90 \%$ yield loss. It causes considerable yield loss of 250000 tonnes of grains/annum worth more than 3750 million rupees per year. Though there are several diseases which attack pigeon pea crop, the major diseases identified in the study area were cercospora leaf spot, fusarium wilt, alternaria blight and sterility mosaic (table 14). Incidence of cercospora leaf spot resulted in to 33.70 per cent loss in yield of pigeon pea. The symptoms of this disease first appear as minute light brown spots, $1-2 \mathrm{~mm}$ in diameter, mainly on the lower surface of the leaves. The spots enlarge to become angular and often several spots coalesce to form irregular blotches. Infection results in to premature defoliation and ultimate reduction in crop yield. Another disease next to the cercospora leaf spot was fusarium wilt, which caused maximum 29.34 per cent yield loss in pigeon pea, with 60.31 per cent area found affected (table 14). Studies confirmed that in wilt disease the plants show signs of gradual wilting, as if affected by drought about five to six weeks after sowing. In severe cases large patches of wilted plants can be found, frequently resulting in more than 50 percent dead plants in the field [Rangaswami and Mahadevan, 2005] $]^{21}$. Diseases like sterility mosaic and alternaria blight inflicted less damage as compared to the above discussed diseases.

Table 13 Pulses area (\%) affected and yield loss (\%) due to major biotic constraints (Insect pests) in Assan valley

\begin{tabular}{|l|l|l|l|l|l|}
\hline Crop & Insect-pest & $\begin{array}{c}\text { Area affected } \\
(\mathbf{\%})\end{array}$ & $\begin{array}{l}\text { Yield loss } \\
(\boldsymbol{\%})\end{array}$ & Rank & $\begin{array}{l}\text { Probability } \\
\text { of occurrence }\end{array}$ \\
\hline Chickpea & Gram Pod borer & 93.38 & 43.80 & 1 & $5 / 5$ \\
\hline & Cutworm & 65.52 & 30.09 & 2 & $4 / 5$ \\
\hline & Tobacco caterpillar & 53.11 & 24.93 & 3 & $3 / 5$ \\
\hline & Termite & 26.12 & 15.28 & 4 & $5 / 5$ \\
\hline Lentil & Gram Pod borer & 65.42 & 24.3 & 1 & $3 / 5$ \\
\hline & Termite & 62.50 & 31.4 & 2 & $4 / 5$ \\
\hline Black gram & Bhar hairy caterpillar & 81.25 & 19.95 & 2 & $3 / 5$ \\
\hline & Gram pod borer & 81.46 & 34.24 & 1 & $3 / 5$ \\
\hline & Termite & 43.03 & 14.49 & 3 & $4 / 5$ \\
\hline Pigeonpea & Gram Pod borer & 90.25 & 43.86 & 1 & $5 / 5$ \\
\hline & Spotted pod borer & 69.50 & 30.19 & 2 & $4 / 5$ \\
\hline & Tur pod bug & 57.46 & 24.93 & 3 & $3 / 5$ \\
\hline & Termite & 45.72 & 17.08 & 4 & $4 / 5$ \\
\hline
\end{tabular}

Table 14 Pulses area (\%) affected and yield loss (\%) due to major biotic constraints (Disease) in Assan valley

\begin{tabular}{|l|l|l|l|l|l|}
\hline Crop & Disease & $\begin{array}{c}\text { Area affected } \\
(\mathbf{\%})\end{array}$ & $\begin{array}{c}\text { Yield loss } \\
(\mathbf{\%})\end{array}$ & Rank & $\begin{array}{l}\text { Probability } \\
\text { of occurrence }\end{array}$ \\
\hline Chickpea & Fusarium wilt & 72.16 & 48.29 & 1 & $4 / 5$ \\
\hline & Rhizoctonia root rot & 48.89 & 33.66 & 2 & $3 / 5$ \\
\hline & Ascochyta blight & 39.28 & 25.52 & 3 & $3 / 5$ \\
\hline & BGM & 29.20 & 20.88 & 4 & $3 / 5$ \\
\hline Lentil & Fusarium wilt & 64.56 & 29.98 & 1 & $3 / 5$ \\
\hline & Lentil rust & 63.65 & 21.22 & 2 & $3 / 5$ \\
\hline Black gram & Yellow mosaic & 91.57 & 62.57 & 1 & $4 / 5$ \\
\hline & Fusarium wilt & 63.54 & 30.48 & 2 & $3 / 4$ \\
\hline
\end{tabular}


"Economic Analysis Of Pulses Production Their Benefits And Constraints"(A Case Study Of Sample)

\begin{tabular}{|l|l|l|l|l|l|}
\hline Pigeonpea & Cercospora leaf spot & 68.81 & 33.70 & 1 & $4 / 5$ \\
\hline & FusariumWilt & 60.31 & 29.34 & 2 & $4 / 5$ \\
\hline & Alternaria blight & 33.47 & 14.71 & 3 & $3 / 5$ \\
\hline & Sterility mosaic & 23.47 & 10.48 & 4 & $3 / 5$ \\
\hline
\end{tabular}

Note: BGM stand for Botrytis gray mold

\subsection{Terminal Drought}

\section{A biotic Constraints In Pulses}

There has been a high degree of risk in pulses production. More than $87 \%$ of the area under pulses is presently rainfed [Reddy 2009] ${ }^{22}$. The mean rainfall of major pulse growing states of India is $1,000 \mathrm{~mm}$ and the coefficient of variation of the rainfall is $20-25 \%$. Moisture stress is the oft-cited reason for crop failures. Terminal drought and heat stress results in forced maturity with low yields. Drought stress alone may reduce seed yields by $50 \%$ in the tropics.

Drought is also serious abiotic constraint in pulses (chickpea and lentil) production in Assan valley of Uttarakhand. Farmers in northern part of Assan Valley (Nayagaon and Jingwreri), reported that 50\% area affected of chickpea due to drought. This result consequently in $50 \%$ yield losses of chickpea production. In southern part farmers reported that $67 \%$ area affected of chick pea from drought. Its result is $55 \%$ yield loss. In chickpea the average affected area and yield loss due to drought was 58.5 and $52.5 \%$, respectively (table 15). The probability of drought occurrence in Assan valley had been 3/5. The area affected of lentil from drought is also found in the Valley. Farmers of northern part of the valley reported that more than $70 \%$ area affected due to drought. The yield loss reported was $36 \%$. While in southern part of Assan Valley, farmers reported that $92 \%$ area was affected by drought, while yield loss was $42 \%$. In lentil the average affected area and yield loss due to drought was 81 and $39 \%$, respectively. Probability of drought occurrence in lentil was twice in every five years (table 15).

Table 15. Pulses area (\%) affected and yield loss (\%) due to major abiotic constraints (Drought) in Assan valley.

\begin{tabular}{|l|l|l|l|}
\hline Crop & $\begin{array}{l}\text { Area affected } \\
(\%)\end{array}$ & $\begin{array}{l}\text { Yield loss } \\
(\%)\end{array}$ & $\begin{array}{l}\text { Probability } \\
\text { of occurrence }\end{array}$ \\
\hline Chickpea & 58.5 & 52.5 & $3 / 5$ \\
\hline Lentil & 81 & 39 & $2 / 5$ \\
\hline
\end{tabular}

Based on household survey in study area, 2009-10

\subsection{Excess soil moisture and humidity}

Water-logging during seed germination and initial seeding growth phase is a constraint for legumes that are introduced into rice-fallows of northern part of Assan Valley and some southern part of the Valley. High humidity during vegetative growth stages (particularly during November to January) makes certain legumes (e.g., chickpea and lentil) susceptible to diseases such as BGM. This can happen in some years, where excessive rainfall occurs during the winter that can encourage excessive vegetative growth leading to lodging, and also encourage development of various leaf and root diseases. Due to excessive rainfall at reproductive phase affects the physically damage of the flowers and developing pods/ seeds and also encourage foliar diseases such as BGM in chickpea, rust and stemphylium blight in lentil [Subbarao et al. 2001] ${ }^{23}$.

\subsection{Temperature}

Grain yield is mainly influenced by temperature. Cold is an abiotic stress, limiting the grain yield of pulse crops. All hot season pulses are sensitive to low temperatures, but generally these are not exposed to low temperatures. On the other hand, cool season pulses (chickpea) are often subjected to chilling temperatures especially in areas of north India. However there has not been much improvement in the development of chilling and frost tolerant varieties.

\subsection{Soil acidity}

Soil acidity was a serious constraint to legume introduction into rabi season as some soil of northern part of Assan Valley have pH value below 6.0. ( Soil Test Lab Report Department of Agriculture S.G.R.R.(P.G) College, (Dehradun), Legumes are more sensitive to soil acidity as compared to cereals and other non-legumes crops [Choudhary and Pande $1986^{24}$, Chong et al. 1987] ${ }^{25}$.

\subsection{Uncertainty in Rainfall}

Uncertainty in rainfall is a serious abiotic constraint in pulses especially in black gram and pigeon pea in northern part and some southern part of Assan Valley. In last few years increase in rainfall have been recorded [Metrological Department, Dehradun 2008-09] ${ }^{26}$ during rainy season (June to August) in Assan Valley 
of Dehradun, resulting decrease in yield of legumes. In pigeon pea the average affected area and yield loss due to drought was 73.75 and $35 \%$, respectively. Probability of drought occurrence in pigeon pea was twice in every five years (16). While an average 70\% area of black gram was affected by rainfall in Assan valley with $40 \%$ yield loss and probability of occurrence $2 / 5$ (table 16). Poor drainage/water stagnation during the rainy season causes heavy losses to pigeonpea on account of low plant stand and increased incidence of phytophthora blight disease, particularly in the states of UP, Bihar, West Bengal, Chhattisgarh, MP and Jharkhand. Ridge planting has been found very effective in ensuring optimal plant stand and consequently higher yield. A simple ridger already available can effectively be used for this purpose. Since most pulse crops are drought tolerant, most of the research efforts have been confined to develop genotypes and associated production technologies to suit dry land conditions. Consequently, germplasm suited to high rainfall and irrigated conditions are lacking [Raddy $2009]^{22}$

Table 16. Pulses area (\%) affected and yield loss (\%) due to major abiotic constraints (rainfall) in Assan valley

\begin{tabular}{|l|l|l|l|}
\hline Crop & $\begin{array}{l}\text { Area affected } \\
(\%)\end{array}$ & $\begin{array}{l}\text { Yield loss } \\
(\%)\end{array}$ & $\begin{array}{l}\text { Probability } \\
\text { of occurrence }\end{array}$ \\
\hline Black gram & 70 & 40 & $2 / 5$ \\
\hline Pigeonpea & 73.75 & 35 & $2 / 5$ \\
\hline
\end{tabular}

Source: Based on household survey in study area, 2009-10

\section{Socio Economic Constraints In Pulses Production}

Lack of knowledge, non availability of improved seed, poor technical guidance were few socio economic institutional constraints [Subbarao et al. $2001^{23} \&$ Pande et al 2003] ${ }^{12}$ while seed storage, poor irrigation and poor marketing were socio economic infrastructural constraints in pulses production [Pande et al. $2003]^{12}$. The following are the main Institutional and Infrastructural constraint in pulses production that has been identified through PRA and RRA with the farmers in Assan Valley shown in table $17 \& 18$. The PRA/RRA data revealed that the lack of knowledge stood on $1^{\text {st }}$ rank during data analysis. As far as pulses production is concerned this is an important constraint. The availability of seed is $2^{\text {nd }}$ important institutional constraints. This may be because farmers are not aware about HYV of pulses seeds; otherwise farmer could have given it rank $1^{\text {st }}$. Lack of technical knowledge regarding improved pulses cultivation is the $3^{\text {rd }}$ ranked constraints cited by the farmers of Assan Valley. Agro chemical and inputs are $4^{\text {th }}$ and $5^{\text {th }}$ institutional constraints cited by the farmers (table 17). Among infrastructural constraints in pulses production; seed storage got the $1^{\text {st }}$ rank (table 18). As far as pulses production is concerned this is an important constraint, because the farmer of Assan Valley has no proper facility of seed storage. Due to lack of knowledge of HYV seed farmers often use their own seed of local varieties, which are often of low quality due to preservation under defective storage systems. Use of low quality seed results in poor plant stand, susceptibility to seedling diseases, and ultimately poor yields [Subbarao et al. 2001] ${ }^{23}$. Hence this is the major infrastructural constraints in Assan Valley. The poor marketing of legumes is $2^{\text {nd }}$ important infrastructural constraints cited by the farmers of Assan valley in PRA/RRA. Markets for legumes are thin and fragmented in comparison with rice and wheat [Byerlee and White 1997$]^{27}$. It is generally perceived that the government procurement for legumes is not as effective as it is for rice and wheat, and often, farmers do not realize the minimum price announced by the government. Also the price spread (i.e., the market margin) for legumes is much higher than that of rice and wheat [Joshi and Pande 1996$]^{28}$. Because of this, farmers do not benefit by the higher market prices of legumes, as most of the profits go to the traders, rather than to the farmers. Hence the farmers are less motivation for pulses cultivation and thus, the serious threat to sustainable agriculture system and the economy of the country. Poor transportation is $3^{\text {rd }}$ rank given by the farmers. This problem is more commonly found in southern part of Assan Valley especially in Bahuwala and Haripur. Poor irrigation got the $4^{\text {th }}$ rank which is given by the farmers in PRA/RRA (table 18). This problem is much found in southern part of the Assan valley.

Table 17. Institutional constraints of pulses production in Assan Valley

\begin{tabular}{|l|l|l|}
\hline Constraints & Percentage & Rank \\
\hline Lack of knowledge & 37 & 1 \\
\hline Seed not available & 31 & 2 \\
\hline Poor technical guidance & 18 & 3 \\
\hline Agro-chemical & 9 & 4 \\
\hline Inputs (fertilizers) & 5 & 5 \\
\hline
\end{tabular}

Source: Based on household survey in study area 2008-09. 


\begin{tabular}{|l|l|l|}
\hline Infrastructural & Percentage & Rank \\
\hline Seed storage & 59 & 1 \\
\hline Poor Marketing & 18 & 3 \\
\hline Poor Transport & 14 & 2 \\
\hline Poor irrigation & 9 & 4 \\
\hline
\end{tabular}

Source: Based on household survey in study area 2008-09.

\section{Conclusion \& Suggestion}

This research has found that the pulses production has declined sharply in the Assan Valley sample villages of Uttarakhand, since 1990 till date. The same trend is found in the state of Uttarakhand as well as in India. The secondary data has revealed that the trend is same in the SAARC Countries too. This has happened due to the persistent problems of biotic factors (insect and diseases), abiotic factors (climate, uncertainties of rainfall, excessive temperature, etc.), institutional and infrastructural constraints, technology related constraints etc. The state is threatened because most of the farmers are growing pulses inefficiently from economic point of view. Inefficient production and low profitability are mainly due to insect damage, disease, and the inferior quality seeds of pulses, and non availability of improved varieties and lack of knowledge about production technologies.

Economic analysis of lentil and chickpea cultivation presented in this study suggests that pulses can be profitably cultivated in rice fallows in the post rainy season. Legumes also contribute in saving $\mathrm{N}$ fertilizer and thus a decline in cost of production. Farmers' perceptions and literature reviewed both revealed that inclusion of legumes in cereal-based cropping systems increased the yield of subsequent cereal crops and reduce the fertilizer cost too.

To enhance the production and profitability of pulses, better quality and high yielding varieties should be available to the farmers of Uttarakhand. The training about HYV seed of pulses should be given to the small and marginal farmers of Assan Valley of Uttarakhand. Development of appropriate legumes technologies, their effective demonstration and seed sector support as well as IPM/ICM/IDM support system is needed to encourage farmers in Uttarakhand to grow legumes to increase their income and improve soil fertility status, and thus enhance the sustainability of the rice-wheat based system.

\section{Reference}

[1]. Joshi, P.K. 1998. Performance of Grain Legumes in the Indo-Gangetic Plain. In J.V.D.K. Kumar Rao, C. Johansen (ed.) Residual Effects of Legumes in Rice and Wheat Cropping Systems of the Indo-Gangetic Plain. International Crop Research Institutes for Semi-Arid Tropics (ICRISTAT). Oxford and IBH Publishing Co. Pvt. Ltd, New Delhi, 1998. ISBN 81-204-1297-4. pp 3-12

[2]. Hobbs, P., and Morris, M. 1996. Meeting South Asia's future food requirements from rice-wheat cropping systems: priority issues facing researches in the post green revolution era. Natural Resource Group Paper 96-101. Mexico: Centro International de Mejoramiento de Maiz y Trigo

[3]. Ahlawat, I.P.S., Ali, M., Yadav, R.L., Kumar Rao, and Rego, T.J. 1998. Biological nitrogen fixation and residual effects of summer and rainy season grain legumes in rice and wheat cropping systems of the Indo-Gangetic Plain. In J.V.D.K. Kumar Rao, C. Johansen (eds.) Residual Effects of Legumes in Rice and Wheat Cropping Systems of the Indo-Gangetic Plain. International Crop Research Institutes for Semi-Arid Tropics (ICRISTAT). Oxford and IBH Publishing Co. Pvt. Ltd, New Delhi, 1998. ISBN 81-2041297-4, pp 31-54

[4]. Lauren, J.G., Duxbury, J.M., Beri, VS., Razzaque II, M.A., Sattar, M.A., Pande, S.P., Bhattarai, S. Mann, R.A., and Ladha, J. K. 1998. Direct and residual effects from forage and green manure legumes in rice-based cropping systems. In J.V.D.K. Kumar Rao, C. Johansen (ed.) Residual Effects of Legumes in Rice and Wheat Cropping Systems of the Indo-Gangetic Plain. International Crop Research Institutes for Semi-Arid Tropics (ICRISTAT). Oxford and IBH Publishing Co. Pvt. Ltd, New Delhi, 1998. ISBN 81-2041297-4, pp 55-82.

[5]. Yadav, R. 1., Dwivedi, B. S., Gangwar, K. S., and Prasad, K. 1998. Over view and prospects for enhancing residual benefits of legumes in rice and wheat cropping systems in India. In J.V.D.K. Kumar Rao, C. Johansen (ed.) Residual Effects of Legumes in Rice and Wheat Cropping Systems of the Indo-Gangetic Plain. International Crop Research Institutes for Semi-Arid Tropics (ICRISTAT). Oxford and IBH Publishing Co. Pvt. Ltd, New Delhi, 1998. ISBN 81-204-1297-4, pp 207-226

[6]. Chambers, R. 1981. 'Rapid Raual Appraisal (RRA): Rational and Repertorie', Public Adminstration Development, pp 95-102.

[7]. Chambers, R. 1992. Participatory Rural Appraisal (PRA): Past, Present and Future Forest, Trees and People Newsletter 15/16, pp 84-87

[8]. Fals Borda and Rehman, 1991 Three Approaches to Participative Inquiry. 1991, Public Administrative Development, pp 6-30

[9]. Parsad, C and Verma, V.K. 1975. Studies in Basin Morphometry and slope development in the western Doon Valley, Garhwal Himalaya. Himalayan Geology Vol. 5 pp 344-425Agriculture statistics data 2009-10. Directorate of Agriculture, Uttarakhand.

[10]. Martin, D and Sahs, S.K. 2007. Journal of Indian Society of Remote Sensing (In Integrated Approach of using Remote Sensing and GIS to study watershed Prioritization), Vol. 35

[11]. Directorate of Agriculture, Government of Uttarakhand 2008-09.

[12]. Pande, S., Bourai, V.A., Neupane, R.K. and Joshi, P.K. 2003. Chickpea Production Constraints and Promotion of integrated Pest Management in Nepal. On -farm IPM of Chickpea in Nepal-1. Information bulletin no. 64. Patancheru, 502 324, Andhra Pradesh, India. International Crops Research Institutes for the Semi-Arid Tropics (CRISTAT), Department for International Development (DFID). pp 4-8. ISBN 92- 9066-462-2.

[13]. Kumar Rao, J.V.D.K., Dart, P.J., and Sastry, P.V.S.S. 1983. Residual effects of Pigeon pea on yield and nitrogen response of maize 19:131:141 
[14]. Kumar Rao, J.V.D.K. and Sithanantham, S. 1989. Impact of nodule damage by Rivellia angulata on $\mathrm{N}_{2}$ fixation, growth and yield of pigeon pea grown in a Vertisol. Biology and fertility of soils. 7:95-100.

[15]. Kumar Rao, J.V.D.K. 1990. Pigeon pea: Nitrogen fixation. In: the Pigeon pea (Y.L. Nene, S.D. Hall, and V.K. Sheila, eds.). Wallingford UK. CAB International, pp. 233-242.

[16]. Bourai, V.A., Pande, S., Neupane, R.K., Stevenson, P.C., Grzywacz, D. Rao, J.N. and Kishore G.K. 2004. Integrated Crop Management of chickpea in Nepal: Past, Present and Future. Pages 16-24 in Policy and strategy for increasing income and food security through improved crop management of chickpea in rice fallow in Asia: proceedings Summary of a NARC-ICRISAT-NRI Workshop held in Kathmandu, Nepal, 17-18 November 2004 (Pande, S., Neupane, R. K., Stevenson, P. C., and Grzywacz, D. eds.). Patancheru, Andhra Pradesh, India: International Crops Research Institute for the Semi- Arid Tropic (ICRISAT) funded by the Department for International Development (DFID) and Crop Protection Programme.

[17]. Reddy, M.V., Singh, O., Bharti, M.P., Sah, R.P. and Joshi, S. 1990. Botrytis grey mould: epiphytotics of chickpea in Nepal. International Chickpea Newsletter, 19:15.

[18]. Grewal, J.S. 1988. Diseases of pulse crop: An overview. Indian Phytopathology, 36:1-14.

[19]. Banu M.R., Muthiah, A.R. and Ashok, S. 2005. Evaluation of pigeonpea (Cajanus cajan L.) genotypes against gram-pod borer (Helicoverpa armigera). In : $4^{\text {th }}$ International Food Legume Research Conference on Food Legumes for Nutritional Security and Sustainable Agriculture, Oct. 18-22, 2005, New Delhi, India. pp. 317.

[20]. Singh, R.S. 2005. Plant diseases. Oxford and IBH, New Delhi. pp.451

[21]. Rangasawami, G and Mahadevan, A.2005. Diseases of crop plants in India. Prentice hall of India, Pvt. Ltd., New Delhi.pp.536.

[22]. Reddy, A A (2009): "Pulses Production Technology: Status and Way Forward", Economic \& Political Weekly, 26 December, vol. xliv no 52 , pp 73-80

[23]. Subbarao, G.V., Kumar Rao, J.V.D.K., Kumar, J., Debb, U.K., Ahmed, I., Harris D, et al. 2001. Spatial Distribution and Quantification of Rice-Fallows in South Asia- Potential for Legumes. International Crops Research Institute for Semi-Arid Tropics (ICRISTAT), National Remote Sensing Agency (NRSA) and Department for International Development (DFID). pp 74-80. ISBN 92-9066-436-3.

[24]. Choudhary, M.A. and Pandey, R.K. 1986. Extending limits to legume crop establishment in rainfed lowland rice. Pages 235-239 in Food legumes improvement for Asian farming systems: proceedings of an international Workshop held in Khon Kaen, Thailand, 1 5 September 1986 (Wallis, E.S., and Byth, D.E., eds.). ACIAR Proceedings no. 18. Canberra, Australia: Australian Centre for International Agricultural Research.

[25]. Chong, K., Wynne, V., Elkan, G.H., and Schneewies, T.G. 1987. Effects of soil acidity and aluminium content on Rhizobium inoculation, growth and nitrogen fixation of groundnut and other legumes. Tropical Agriculture 64:97-104.

[26]. Metrological Department Dehradun, Govt. of India 2008-09.

[27]. Byerlee, D., and White, R. 1997. Agriculture systems intensification and diversification through food legumes: technological and policy options. Presented at the III International Food Legumes Research Conference, 22-26 September 1997, Adelaide, Australia.

[28]. Joshi, P.K., and Pande, S. 1996. Constraints to and prospects for adoption of extra-short duration pigeon pea in northern India: Some socio-economic aspects. Pages 106-115 in Prospects for growing extra-short duration pigeon pea in rotation with winter crops: proceedings of the IARI/ICRISAT workshop and Monitoring tour, 16-18 October 1995, New Delhi, India. Patancheru 502 324, Andhra Pradesh, India: International Crops Research Institute for Semi-Arid Tropics.

[29]. Jeswani, L.M. and Baldev, B., Advances in Pulse Production Technology, Indian Council of Agricultural Research Publication (1988). Pp 137-139

[30]. Joshi, P.K., Birthal, S. and Bourai, V.A. 2002. Socioeconomic constraints and opportunities in rainfed rabi cropping in rice fallow areas of India. Patancheru, 502 324, Andhra Pradesh, India. International Crops Research Institute for the Semi-Arid Tropics. Submitted by National Centre for Agricultural Economics and Policy Research Library Avenue, Pusa, New Delhi 110 012, India. 